\title{
Problem częstotliwości drgań własnych w wirujących układach mechanicznych pojazdów szynowych
}

\begin{abstract}
Na przykładzie wirujacego koła kolejowego przedstawiono wyniki obliczeń numerycznych problemu brzegowego układu równań opisujacych drgania koła. Wirujace koło zamodelowano jako układ ciagły. Opracowano kilka wariantów modelu fizycznego i matematycznego koła, poczynajac od modelu najprostszego, $w$ którym przyjęto petnq symetrię struktury wirujacego koła, aż do modelu z asymetriq struktury (niewyważenia tarczy $i$ wieńca koła o ciagłym rozkładzie masy) $w$ ruchu tocznym $i$ wspótpraca z torem. W zależności od przyjętego modelu wyniki obliczeń wykazuja duże różnice ilościowe, a przede wszystkim jakościowe.

Praca została wykonana $w$ ramach projektu badawczego Komitetu Badań Naukowych realizowanego w latach 2003-2006.
\end{abstract}

\section{Wstęp}

W badaniach dynamiki układu koło-szyna, gdzie interesują nas głównie drgania kontaktowe, najczęściej jako model pojazdu przyjmuje się koło lub zestaw kołowy, na który działa zadane obciążenie statyczne. Zwykle zakłada się, że koło jest idealnie sztywne z ewentualnym elementem sprężystym tzw. sprężyną Hertza modelującą współdziałanie $\mathrm{z}$ torem oraz przyjmuje się, że koło wykazuje pełną symetrię kołową. Analiza dynamiczna tego tradycyjnego modelu koła pozwala na badanie zjawisk w niskim zakresie częstotliwości drgań i prędkości. Granica stosowalności modelu „sztywnego koła”, która określona jest przez najniższą wartość częstotliwości jego drgań własnych, stała się impulsem do podjęcia prac nad dynamicznym modelem koła, który uwzględniałby jego odkształcenia sprężyste, a także umożliwiałby uwzględnienie $\mathrm{w}$ analizie naruszenie symetrii struktury koła. Asymetria struktury jest nieodłączną cechą rzeczywistych układów mechanicznych. Jest ona skutkiem tolerancji wymiarowych dopuszczalnych w procesie wytwarzania lub nierównomiernego zużycia w procesie eksploatacji.

W celu istotnego poprawienia dokładności modelowania, efektywności i stabilności numerycznej dotychczas stosowanych modeli i metod np. modelu MES, w analizie dynamicznej proponuje się wykorzystać przedstawiony analityczny model koła.

\section{Model fizyczny koła}

Przestrzenny model fizyczny koła kolejowego utworzony jest $\mathrm{z}$ jego wieńca, modelowanego jako sprężysta zakrzywiona belka pryzmatyczna, połączonego z osią zestawu kołowego ciagłym inercyjnym podłożem sprężystym typu Winklera o charakterystyce liniowej. Podłoże sprężyste tworzy tarczę koła.

Przy modelowaniu niewyważeń koła przyjęto następujące podstawowe założenia:

- niewyważenia są skutkiem ciągłego nierównomiernego rozkładu masy,

- niewyważenia mogą występować na wieńcu i tarczy koła,

- niewyważenia wieńca i tarczy mogą być różne i przesunięte w fazie,

- pomija się niewyważenia piasty koła i podpiaścia osi (małe przyśpieszenia względne),

- rozkład niewyważeń na obwodzie koła ma charakter harmoniczny.
W rzeczywistości niewyważenia koła są skutkiem dopuszczalnych tolerancji wymiarowych, które powstają w procesie wytwarzania np. tolerancja szerokości wieńca, grubości tarczy koła itp. Mogą one być w łatwy sposób przeliczone na lokalną zmianę gęstości materiału. Przyjęcie dwóch ostatnich założeń prowadzi do wniosku, że niewyważenia modeluje się w sposób przybliżony jako harmoniczną zmianę gęstości materiału wieńca lub tarczy na obwodzie koła. Konsekwencją przyjętego rozkładu niewyważeń jest to, że również takie parametry jak sztywność (obwodowa, radialna i binormalna) tarczy koła, masowe momenty bezwładności, zredukowane współczynniki tłumienia itp. są funkcją niezależnej zmiennej przestrzennej $\varphi$.

W przypadku modelowania koła poruszającego się ruchem tocznym po torze zakłada się ruch prostoliniowy ze stałą prędkością $V$. Środek masy koła, na który działa zewnętrzne obciążenie $Q$ może wykonywać ruch jedynie w kierunku pionowym. Pozostałe punkty materialne koła mogą przemieszczać się przestrzennie. Współpracę koła $z$ szyną zamodelowano liniowymi sprężynami Hertza, przenoszącymi siły w trzech kierunkach: podłużnym, pionowym, poprzecznym oraz moment wiertny. Sztywności sprężyn Hertza wynoszą odpowiednio $k_{H u}, k_{H v}, k_{H w}$, i $k_{s}$. Zakłada się, że w punkcie styku nie występuja poślizgi, a siły kontaktowe $P_{x}, P_{y}, P_{z}$ i moment spinu $M_{S}$ mają charakter sił skupionych:

$$
\begin{gathered}
P_{x}=\mu_{T} k_{H_{v}}\left(z+v_{S}\right)-k_{H_{u}} u_{S}, \\
P_{y}=-k_{H_{w}} w_{S} \\
P_{z}=-k_{H_{v}}\left(z+v_{S}\right), \\
M_{S}=a_{S} \mu_{T} k_{H_{v}}\left(z+v_{S}\right)-a_{S} k_{H_{v}} u_{S}-k_{S} \vartheta_{\eta},
\end{gathered}
$$

gdzie:

$u_{S}, v_{S}, w_{S}-$ przemieszczenie punktu styku odpowiednio względem osi $x, z$ i $y$ (wzdłużnej, pionowej i poprzecznej),

$\vartheta_{\eta}$ - obrót przekroju wieńca (przechodzącego przez punkt styku) względem osi pionowej,

$\mu_{T}$ - współczynnik oporu toczenia.

$a_{s}$ - odległość między punktem styku a geometryczną osią wieńca, mierzona w kierunku poprzecznym. 


\section{Model matematyczny koła}

Równania drgań wirującego koła zostały wyprowadzone przy wykorzystaniu zasady d'Alemberta. W przypadku koła wykonującego wyłącznie ruch obrotowy, jego model matematyczny stanowi układ sześciu cząstkowych równań różniczkowych, z których trzy opisują drgania odpowiednio względem osi stycznej, normalnej i binormalnej w stosunku do geometrycznej osi wieńca, a pozostałe trzy opisują obroty przekroju poprzecznego wieńca względem tych osi. Równania te są sprzężone siłami sprężystości i siłami bezwładności. Siły sprężystości i bezwładności powodujące sprzężenie drgań wynikają z asymetrycznego przekroju poprzecznego wieńca, niewyważeń oraz przyśpieszenia Coriolisa. Z uwagi na skomplikowaną budowę równań zrezygnowano tutaj $\mathrm{z}$ prezentacji modelu matematycznego a pełną jego postać można znaleźć w [1], gdzie podano również bardziej wyczerpujący i szczegółowy opis modelu fizycznego i zasad modelowania niewyważeń koła.

Przy analizie dynamicznej koła poruszającego się ruchem tocznym, w modelu matematycznym należy uwzględnić działające siły stykowe wg (1) oraz uzupełnić układ dodatkowym równaniem, które opisuje drgania środka masy koła względem osi pionowej $z$. Równanie to ma następującą postać:

$$
\begin{aligned}
& M_{k} \ddot{z}+k_{H_{v}} z=-Q-k_{H_{v}}\left(v-a_{S} \vartheta\right)_{\varphi_{1}=\pi}+\int_{0}^{2 \pi}\left\{( \rho + \Delta \rho ) \operatorname { c o s } k \varphi \left[\frac{\partial^{2}}{\partial t^{2}}\left(R A u-J_{11} \vartheta_{\eta}+J_{20} \vartheta_{\zeta}\right)-\right.\right. \\
& \left.-2 \dot{\varphi_{o}} \frac{\partial}{\partial t}\left(R A v+J_{11} \vartheta\right)\right]+m_{u} \frac{\partial^{2}}{\partial t^{2}}\left(u+h_{o} \vartheta_{\eta}-h \vartheta_{\zeta}\right)-2 m_{v} \dot{\varphi}_{o} \frac{\partial}{\partial t}\left(v-h_{o} \vartheta\right)+ \\
& \left.+\cos (l \varphi+\alpha)\left[\Delta m_{u} \frac{\partial^{2}}{\partial t^{2}}\left(u+h_{o} \vartheta_{\eta}-h \vartheta_{\zeta}\right)-2 \Delta m_{v} \dot{\varphi}_{o} \frac{\partial}{\partial t}\left(v-h_{o} \vartheta\right)\right]\right\} \sin \varphi_{1} d \varphi_{1}+ \\
& +\int_{0}^{2 \pi}\left\{(\rho+\Delta \rho \cos k \varphi)\left[\frac{\partial^{2}}{\partial t^{2}}\left(R A v+J_{11} \vartheta\right)+2 \dot{\varphi}_{o} \frac{\partial}{\partial t}\left(R A u-J_{11} \vartheta_{\eta}+J_{20} \vartheta_{\zeta}\right)\right]+\right. \\
& +m_{v} \frac{\partial^{2}}{\partial t^{2}}\left(v-h_{o} \vartheta\right)-2 m_{u} \dot{\varphi}_{o} \frac{\partial}{\partial t}\left(u+h_{o} \vartheta_{\eta}-h \vartheta_{\zeta}\right)+ \\
& \left.+\cos (l \varphi+\alpha)\left[\Delta m_{v} \frac{\partial^{2}}{\partial t^{2}}\left(v-h_{o} \vartheta\right)+2 \Delta m_{u} \dot{\varphi}_{o} \frac{\partial}{\partial t}\left(u+h_{o} \vartheta_{\eta}-h \vartheta_{\zeta}\right)\right]\right\} \cos \varphi_{1} d \varphi_{1}{ }^{\prime}
\end{aligned}
$$

gdzie:

$u, v, w, \vartheta, \vartheta_{\eta}, \vartheta_{\zeta}$ - przemieszczenia i obroty poprzecznego przekroju wieńca odpowiednio względem osi stycznej, normalnej i binormalnej,

$m_{u}, m_{v}$ - zredukowane masy wieńca i tarczy koła,

$R$ - promień geometrycznej osi wieńca koła,

$A, J_{i j}$ - pole i geometryczne momenty przekroju poprzecznego wieńca,

$k, l$ - liczby naturalne charakteryzujące niewyważenia wieńca i tarczy,

$\alpha$ - kąt przesunięcia fazowego między niewyważeniem tarczy i wieńca,

$\dot{\varphi}_{o}$ - prędkość kątowa koła,

$a_{S}, h, h_{o}$ - wielkości charakteryzujące wymiary koła, $\rho$ - gęstość materiału wieńca koła.

Wielkości występujące w (2) i oznaczone symbolem $\Delta$ oznaczają amplitudę zmian danego parametru, wywołaną niewyważeniem tarczy lub wieńca koła.

\section{Wyniki obliczeń}

Rozwiązania problemu brzegowego jednorodnego układu równań drgań poszukuje się w postaci funkcji o rozdzielonych zmiennych w dziedzinie zmiennej zespolonej dla przypadku $V=$ const. Stosując skończoną transformację sinusową i cosinusową, otrzymuje się w efekcie układ jednorodnych równań algebraicznych, który w przypadku uwzględnienia niewyważeń koła lub/i jego ruchu tocznego jest układem o nieskończenie wielu równaniach. Warunkiem istnienia nietrywialnego rozwiązania tego układu jest zerowanie się wyznacznika głównego. Z uwagi na nieskończony wymiar wyznacznika głównego możliwe jest wyznaczenie częstości drgań z dowolną dokładnością zależną od zastosowanej procedury numerycznej.

Obliczenia numeryczne przeprowadzono dla koła o średnicy nominalnej $0.95 \mathrm{~m}$ i grubości wieńca $0.05 \mathrm{~m}$ oraz dla trzech charakterystycznych przypadków modelu wirującego koła:

- $\quad$ wirujące koło o pełnej symetrii kołowej (tabela 1),

- wirujące koło z niewyważeniami - asymetria struktury (tabela 2),

- $\quad$ koło z niewyważeniami poruszające się ruchem tocznym (rys. 1 i 2 ).

$\mathrm{W}$ celu porównania modelu koła $\mathrm{z}$ wieńcem modelowanym belką Rayleigha lub belką Timoshenki, w tabeli 1 podano wyniki obliczeń numerycznych częstotliwości pięciu pierwszych form drgań własnych koła o pełnej symetrii struktury wraz z ich graficznym przedstawieniem. Analize przeprowadzono rozważając przypadek bez i z uwzględnieniem tarcia wewnętrznego w materiale wieńca i tarczy oraz prędkości kątowej koła, której w ruchu tocznym odpowiada prędkość liniowa $200 \mathrm{~km} / \mathrm{h}$. Każdej formie drgań odpowiadają cztery (belka Rayleigha) lub sześć (belka Timoshenki) wartości częstotliwości. Ruch obrotowy koła powoduje podwojenie się liczby częstotliwości drgań własnych dla każdej formy drgań z wyjątkiem formy "zerowej" (forma z zerową liczbą średnic węzłowych). Zjawisko to znane jest pod nazwą bifurkacji drgań.

W tabeli 2 przedstawiono wyniki obliczeń częstotliwości drgań własnych tego samego koła z pominięciem tłumienia wewnętrznego materiału koła, ale $\mathrm{z}$ naruszoną symetrią struktury. Parametry charakteryzujące niewyważenia koła podano w pierwszym wierszu tabeli. Obliczenia wykonano dla prędkości $V$ równej $0,100,200,300$ i $400 \mathrm{~km} / \mathrm{h}$. Z analizy wynika, że dla koła z niewyważeniami występuje sprzężenie pomiędzy formami ich drgań. Drgania formy o numerze $n=0$ (forma z zerową liczbą średnic węzłowych) sprzężone są z drganiami form $k$ i $l$, a formy, dla których $n=1,2,3,4 \ldots . \mathrm{z}$ drganiami form $|n-k|,|n-l|, n+k$, i $n+l$. W rezultacie każda postać drgań charakteryzuje się nieskończoną liczbą częstotliwości drgań własnych. Dla każdej formy można jednak wyróżnić częstotliwości dominujące tzn. częstotliwości generowane przez tą postać i wyróżniające się dużymi wartościami amplitud. Identyfikacja częstotliwości dominujących możliwa jest po rozwiązaniu zagadnienia początkowego. $\mathrm{Z}$ tabeli 2 wynika, że dla modelu, w którym pominięto tłumienie wewnętrzne, a rozkład masy niewyważeń wykazuje co najmniej jedną oś symetrii, ruch obrotowy koła jest ruchem stabilnym. Należy nadmienić, że równanie charakterystyczne problemu brzegowego wirującego koła jest równaniem źle uwarunkowanym i w związku z tym obliczenia numeryczne muszą być prowadzone $\mathrm{z}$ dużą dokładnością. Wydłuża to oczywiście czas obliczeń numerycznych. Przykładowo, uzyskanie wyników przedstawionych w tabeli 2 przy uwzględnieniu tylko trzech form własnych związane jest $\mathrm{z}$ czasem pracy procesora PC z zegarem $1 \mathrm{GHz}$ wynoszącym ok. $10 \mathrm{~h}$. 
Wyniki obliczeń częstotliwości własnych koła z symetrią struktury

Tabela 1

\begin{tabular}{|c|c|c|c|c|c|c|c|}
\hline \multirow{4}{*}{$\begin{array}{l}\mathrm{Nr} \\
\text { for- } \\
\text { my }\end{array}$} & \multirow{4}{*}{$\begin{array}{c}\text { Forma } \\
\text { drgań } \\
\text { własnych }\end{array}$} & \multicolumn{6}{|c|}{$\begin{array}{l}\text { Częstotliwość drgań własnych f i część rzeczywista Re pierwiastków równania charakterystycznego } \\
\text { przy prędkości } \mathrm{V}=200 \mathrm{~km} / \mathrm{h}\end{array}$} \\
\hline & & \multirow{3}{*}{$\begin{array}{c}\text { Belka } \\
\text { Rayleigha } \\
\mathrm{b}=0, \mathrm{f}[\mathrm{Hz}]\end{array}$} & \multicolumn{5}{|c|}{ Belka Timoshenki } \\
\hline & & & $\mathrm{b}=0$ & \multicolumn{2}{|c|}{$\mathrm{b}=0.001 \mathrm{Ns} / \mathrm{m}^{2}$} & \multicolumn{2}{|c|}{$\mathrm{b}=0.05 \mathrm{Ns} / \mathrm{m}^{2}$} \\
\hline & & & $\mathrm{f}[\mathrm{Hz}]$ & $\mathrm{f}[\mathrm{Hz}]$ & $10^{-9} \mathrm{Re}[1 / \mathrm{s}]$ & $\mathrm{f}[\mathrm{Hz}]$ & $10^{-6} \operatorname{Re}[1 / \mathrm{s}]$ \\
\hline 0 & & $\begin{array}{r}90.06 \\
586.15 \\
1520.18 \\
2748.94\end{array}$ & $\begin{array}{r}90.06 \\
586.14 \\
1518.05 \\
2749.26 \\
10472.50 \\
14248.74\end{array}$ & $\begin{array}{r}90.06 \\
586.14 \\
1518.05 \\
2749.26 \\
10472.50 \\
14248.74\end{array}$ & $\begin{array}{r}-0.78 \\
-83.74 \\
-220.92 \\
-724.13 \\
-26726.49 \\
-49476.29\end{array}$ & $\begin{array}{r}90.06 \\
586.14 \\
1518.05 \\
2749.26 \\
10472.50 \\
14248.74\end{array}$ & $\begin{array}{r}-0.04 \\
-4.19 \\
-11.05 \\
-36.21 \\
-1336.32 \\
-2473.81\end{array}$ \\
\hline 1 & & $\begin{array}{r}94.54 \\
95.03 \\
1270.04 \\
1294.50 \\
1678.38 \\
1680.83 \\
2947.52 \\
2972.31\end{array}$ & $\begin{array}{r}94.54 \\
95.03 \\
1270.36 \\
1294.90 \\
1677.38 \\
1680.55 \\
2947.43 \\
2972.25 \\
10515.16 \\
10517.17 \\
14282.48 \\
14283.85\end{array}$ & $\begin{array}{r}94.54 \\
95.03 \\
1270.36 \\
1294.90 \\
1677.38 \\
1680.55 \\
2947.43 \\
2972.25 \\
10515.16 \\
10517.17 \\
14282.48 \\
14283.85\end{array}$ & $\begin{array}{r}-.90 \\
-.90 \\
-199.24 \\
-203.38 \\
-321.20 \\
-321.50 \\
-842.78 \\
-850.59 \\
-26933.66 \\
-26936.94 \\
-49687.36 \\
-49691.96\end{array}$ & $\begin{array}{r}94.54 \\
95.03 \\
1270.36 \\
1294.90 \\
1677.38 \\
1680.55 \\
2947.43 \\
2972.25 \\
10515.16 \\
10517.17 \\
14282.48 \\
14283.85\end{array}$ & $\begin{array}{r}-0.04 \\
-0.05 \\
-9.96 \\
-10.17 \\
-16.06 \\
-16.07 \\
-42.14 \\
-42.53 \\
-1346.68 \\
-1346.85 \\
-2484.37 \\
-2484.60\end{array}$ \\
\hline 2 & & $\begin{array}{r}306.60 \\
309.36 \\
1701.07 \\
1717.54 \\
2092.69 \\
2112.82 \\
3875.37 \\
3909.58\end{array}$ & $\begin{array}{r}305.03 \\
307.75 \\
1716.86 \\
1734.12 \\
2077.70 \\
2098.64 \\
3872.34 \\
3906.97 \\
10634.09 \\
10637.86 \\
14382.80 \\
14385.35\end{array}$ & $\begin{array}{r}305.03 \\
307.75 \\
1716.86 \\
1734.12 \\
2077.70 \\
2098.64 \\
3872.34 \\
3906.97 \\
10634.09 \\
10637.86 \\
14382.80 \\
14385.35\end{array}$ & $\begin{array}{r}-15.10 \\
-15.17 \\
-391.01 \\
-402.75 \\
-528.93 \\
-524.24 \\
-1475.42 \\
-1487.83 \\
-27537.05 \\
-27543.72 \\
-50318.53 \\
-50327.87\end{array}$ & $\begin{array}{r}305.03 \\
307.75 \\
1716.86 \\
1734.12 \\
2077.70 \\
2098.64 \\
3872.34 \\
3906.97 \\
10634.09 \\
10637.86 \\
14382.80 \\
14385.35\end{array}$ & $\begin{array}{r}-0.75 \\
-0.76 \\
-19.55 \\
-20.14 \\
-26.44 \\
-26.21 \\
-73.77 \\
-74.39 \\
-1376.85 \\
-1377.19 \\
-2515.93 \\
-2516.39\end{array}$ \\
\hline 3 & & $\begin{array}{r}890.60 \\
896.80 \\
1984.94 \\
2008.30 \\
2418.64 \\
2424.67 \\
5323.83 \\
5351.90\end{array}$ & $\begin{array}{r}883.67 \\
889.65 \\
2020.92 \\
2046.66 \\
2391.67 \\
2397.82 \\
5303.56 \\
5332.99 \\
10799.20 \\
10804.28 \\
14543.39 \\
14546.75\end{array}$ & $\begin{array}{r}883.67 \\
889.65 \\
2020.92 \\
2046.66 \\
2391.67 \\
2397.82 \\
5303.56 \\
5332.99 \\
10799.20 \\
10804.28 \\
14543.39 \\
14546.75\end{array}$ & $\begin{array}{r}-124.81 \\
-125.06 \\
-445.67 \\
-460.91 \\
-905.13 \\
-896.21 \\
-2777.71 \\
-2789.95 \\
-28474.94 \\
-28485.30 \\
-51347.99 \\
-51362.57\end{array}$ & $\begin{array}{r}883.67 \\
889.65 \\
2020.92 \\
2046.66 \\
2391.67 \\
2397.82 \\
5303.56 \\
5332.99 \\
10799.20 \\
10804.28 \\
14543.39 \\
14546.75\end{array}$ & $\begin{array}{r}-6.24 \\
-6.25 \\
-22.28 \\
-23.05 \\
-45.26 \\
-44.81 \\
-138.89 \\
-139.50 \\
-1423.75 \\
-1424.26 \\
-2567.40 \\
-2568.13\end{array}$ \\
\hline 4 & & $\begin{array}{l}1717.33 \\
1728.43 \\
2177.86 \\
2205.15 \\
2907.89 \\
2912.09 \\
6910.39 \\
6934.93\end{array}$ & $\begin{array}{r}1690.56 \\
1701.54 \\
2237.13 \\
2265.62 \\
2901.92 \\
2904.19 \\
6848.38 \\
6876.21 \\
10967.02 \\
10972.85 \\
14756.35 \\
14759.90\end{array}$ & $\begin{array}{r}1690.56 \\
1701.54 \\
2237.13 \\
2265.62 \\
2901.92 \\
2904.19 \\
6848.38 \\
6876.21 \\
10967.02 \\
10972.85 \\
14756.35 \\
14759.90\end{array}$ & $\begin{array}{r}-464.37 \\
-466.81 \\
-451.90 \\
-455.28 \\
-1401.69 \\
-1401.39 \\
-4715.96 \\
-4725.24 \\
-29648.32 \\
-29663.45 \\
-52751.68 \\
-52730.28\end{array}$ & $\begin{array}{r}1690.56 \\
1701.54 \\
2237.13 \\
2265.62 \\
2901.92 \\
2904.19 \\
6848.38 \\
6876.21 \\
10967.02 \\
10972.85 \\
14756.35 \\
14759.90\end{array}$ & $\begin{array}{r}-23.22 \\
-23.34 \\
-22.59 \\
-22.76 \\
-70.08 \\
-70.07 \\
-235.80 \\
-236.26 \\
-1482.42 \\
-1483.17 \\
-2636.51 \\
-2637.58\end{array}$ \\
\hline
\end{tabular}

b- współczynnik tłumienia 


\begin{tabular}{|c|c|c|c|c|c|c|c|c|c|}
\hline & $\begin{array}{c}\alpha=0 \\
\mathrm{n}=2 \\
\mathrm{k}=2 \\
\mathrm{l}=2 \\
\rho=79 \mathrm{~kg} / \\
\Delta \mathrm{l}_{\mathrm{t}}=1 \mathrm{mn}\end{array}$ & & & & & & & & \\
\hline \multicolumn{10}{|c|}{$\begin{array}{c}\text { Częstotliwość drgań własnych f i część rzeczywista Re pierwiastków } \\
\text { równania charakterystycznego }\end{array}$} \\
\hline \multicolumn{2}{|c|}{$\mathrm{V}=0$} & \multicolumn{2}{|c|}{$\mathrm{V}=100 \mathrm{~km} / \mathrm{h}$} & \multicolumn{2}{|c|}{$\mathrm{V}=200 \mathrm{~km} / \mathrm{h}$} & \multicolumn{2}{|c|}{$\mathrm{V}=300 \mathrm{~km} / \mathrm{h}$} & \multicolumn{2}{|c|}{$\mathrm{V}=400 \mathrm{~km} / \mathrm{h}$} \\
\hline $\mathrm{f}[\mathrm{Hz}]$ & $\operatorname{Re}[1 / \mathrm{s}]$ & $\mathrm{f}[\mathrm{Hz}]$ & $\operatorname{Re}[1 / \mathrm{s}]$ & $\mathrm{f}[\mathrm{Hz}]$ & $\operatorname{Re}[1 / \mathrm{s}]$ & $\mathrm{f}[\mathrm{Hz}]$ & $\operatorname{Re}[1 / \mathrm{s}]$ & $\mathrm{f}[\mathrm{Hz}]$ & $\operatorname{Re}[1 / \mathrm{s}]$ \\
\hline 96.70 & 0. & 96.70 & 0. & 96.70 & 0. & 96.70 & 0. & 96.70 & 0. \\
\hline 99.27 & 0. & 99.26 & 0. & 99.25 & 0. & 99.23 & 0. & 99.20 & 0. \\
\hline 102.65 & 0. & 102.66 & 0. & 102.67 & 0. & 102.69 & 0. & 102.72 & 0. \\
\hline 308.71 & 0. & 308.04 & 0. & 307.37 & 0. & 306.69 & 0. & 306.01 & 0. \\
\hline 308.74 & 0. & 309.40 & 0. & 310.08 & 0. & 310.76 & 0. & 311.44 & 0. \\
\hline 586.19 & 0. & 586.18 & 0. & 586.14 & 0. & 586.07 & 0 . & 585.97 & 0. \\
\hline 1290.86 & 0. & 1288.12 & 0. & 1283.04 & 0. & 1277.47 & 0 . & 1271.75 & 0. \\
\hline 1300.64 & 0. & 1303.38 & 0. & 1308.42 & 0. & 1313.93 & 0. & 1319.58 & 0. \\
\hline 1518.62 & 0. & 1518.62 & 0. & 1518.63 & 0. & 1518.64 & 0. & 1518.65 & 0. \\
\hline 1683.49 & 0. & 1683.29 & 0. & 1682.80 & 0. & 1682.18 & 0. & 1681.51 & 0. \\
\hline 1686.22 & 0. & 1686.43 & 0. & 1686.93 & 0. & 1687.57 & 0. & 1688.28 & 0. \\
\hline 1741.08 & 0. & 1737.49 & 0. & 1733.81 & 0. & 1730.05 & 0. & 1726.21 & 0. \\
\hline 1741.12 & 0. & 1744.63 & 0. & 1748.09 & 0. & 1751.47 & 0. & 1754.77 & 0. \\
\hline 2137.30 & 0. & 2131.54 & 0. & 2125.81 & 0. & 2120.19 & 0. & 2114.70 & 0. \\
\hline 2137.48 & 0. & 2143.36 & 0. & 2149.45 & 0. & 2155.66 & 0. & 2161.98 & 0. \\
\hline 2859.49 & 0. & 2859.55 & 0. & 2859.73 & 0. & 2860.03 & 0. & 2860.46 & 0. \\
\hline 3050.51 & 0. & 3047.14 & 0. & 3041.65 & 0. & 3035.94 & 0. & 3030.23 & 0. \\
\hline 3058.06 & 0. & 3061.53 & 0. & 3067.28 & 0. & 3073.44 & 0. & 3079.77 & 0. \\
\hline 3936.40 & 0. & 3927.50 & 0. & 3918.53 & 0. & 3909.59 & 0. & 3900.67 & 0. \\
\hline 3936.58 & 0. & 3945.50 & 0. & 3954.54 & 0. & 3963.60 & 0. & 3972.67 & 0. \\
\hline 10434.88 & 0. & 10434.89 & 0. & 10434.92 & 0. & 10434.97 & 0. & 10435.03 & 0. \\
\hline 10454.26 & 0. & 10454.26 & 0. & 10454.29 & 0. & 10454.33 & 0. & 10454.39 & 0. \\
\hline 10580.13 & 0. & 10580.14 & 0. & 10580.17 & 0. & 10580.22 & 0. & 10580.30 & 0. \\
\hline 10637.66 & 0. & 10637.66 & 0. & 10637.65 & 0. & 10637.62 & 0. & 10637.59 & 0. \\
\hline 10677.63 & 0. & 10677.66 & 0. & 10677.73 & 0. & 10677.85 & 0. & 10678.01 & 0. \\
\hline 14153.36 & 0. & 14153.36 & 0. & 14153.36 & 0. & 14153.37 & 0. & 14153.38 & 0. \\
\hline 14177.51 & 0. & 14177.51 & 0. & 14177.51 & 0. & 14177.52 & 0. & 14177.52 & 0. \\
\hline 14386.74 & 0. & 14386.74 & 0. & 14386.74 & 0. & 14386.75 & 0. & 14386.75 & 0. \\
\hline 14393.16 & 0. & 14393.16 & 0. & 14393.17 & 0. & 14393.17 & 0. & 14393.18 & 0. \\
\hline 14488.04 & 0. & 14488.04 & 0. & 14488.05 & 0. & 14488.06 & 0. & 14488.07 & 0. \\
\hline
\end{tabular}

Największe jednak zmiany jakościowe i ilościowe obserwuje się w przypadku analizy drgań własnych koła z niewyważeniami, poruszającego się ruchem tocznym (rys. 1 i 2). Uwzględnienie dodatkowego więzu w postaci sił stykowych powoduje, że w układzie pojawiają się dodatkowe okresowe wymuszenia kinematyczne i dynamiczne, których wielkość zależna jest od czasu i położenia niewyważonych mas względem punktu styku (rys. 2). Dodatkowo sprzężenie to powoduje, że wartości częstotliwości drgań własnych, w tym wartości częstotliwości dominujących danej formy, zmieniają się okresowo (rys. 1). Okres tych zmian równa się okresowi obrotu koła. Obliczenia przedstawione na rys. 1 i rys. 2 wykonano dla koła bez uwzględnienia tłumienia wewnętrznego oraz wymiarach koła i parametrach niewyważeń jak w tabeli 2. Na rys. 1 i rys. 2 zaznaczono numerami odpowiadające sobie krzywe części urojonej i rzeczywistej pierwiastków równania charakterystycznego. 


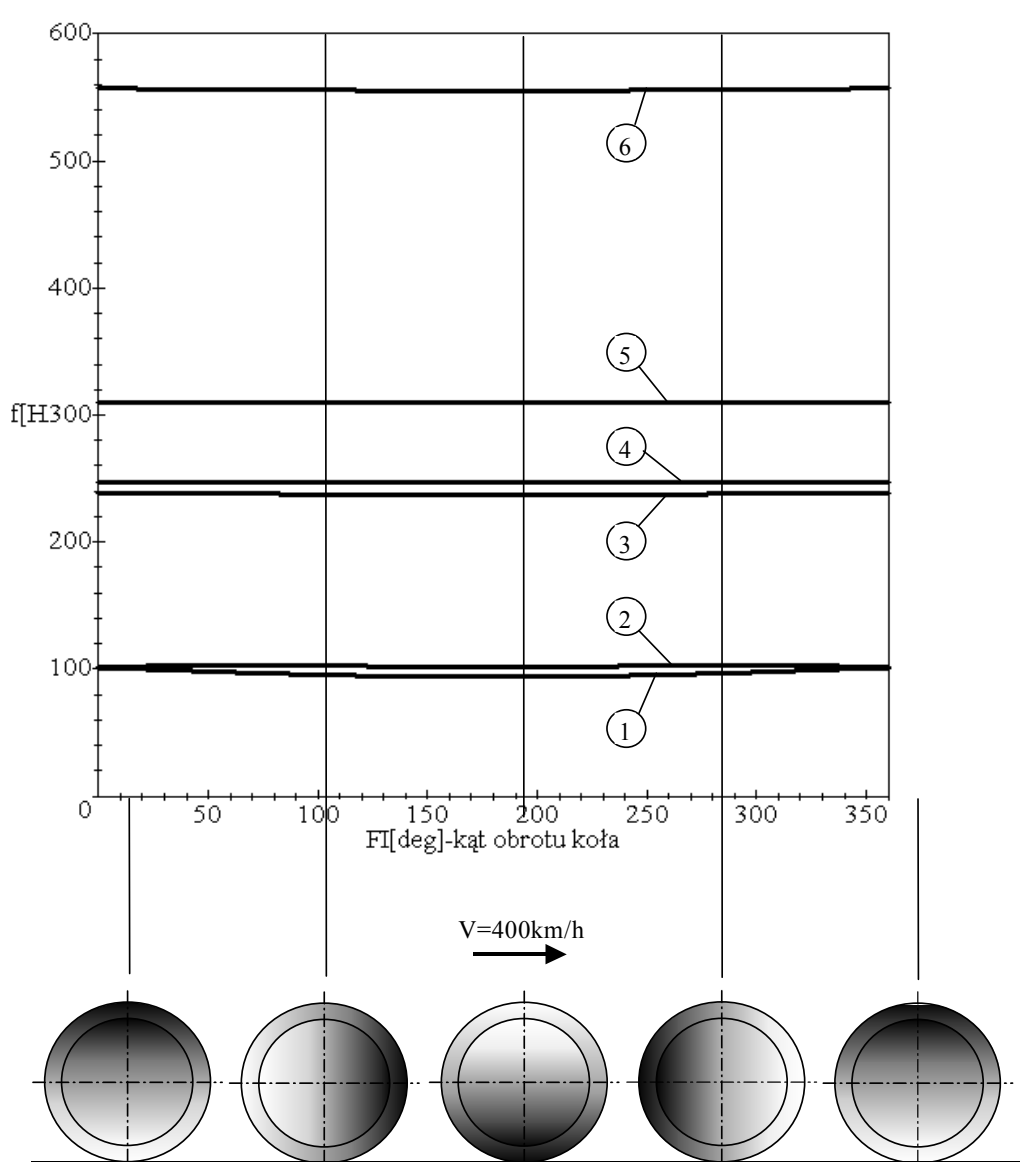

Rys.1. Częstotliwości drgań własnych koła z niewyważeniami w ruchu tocznym

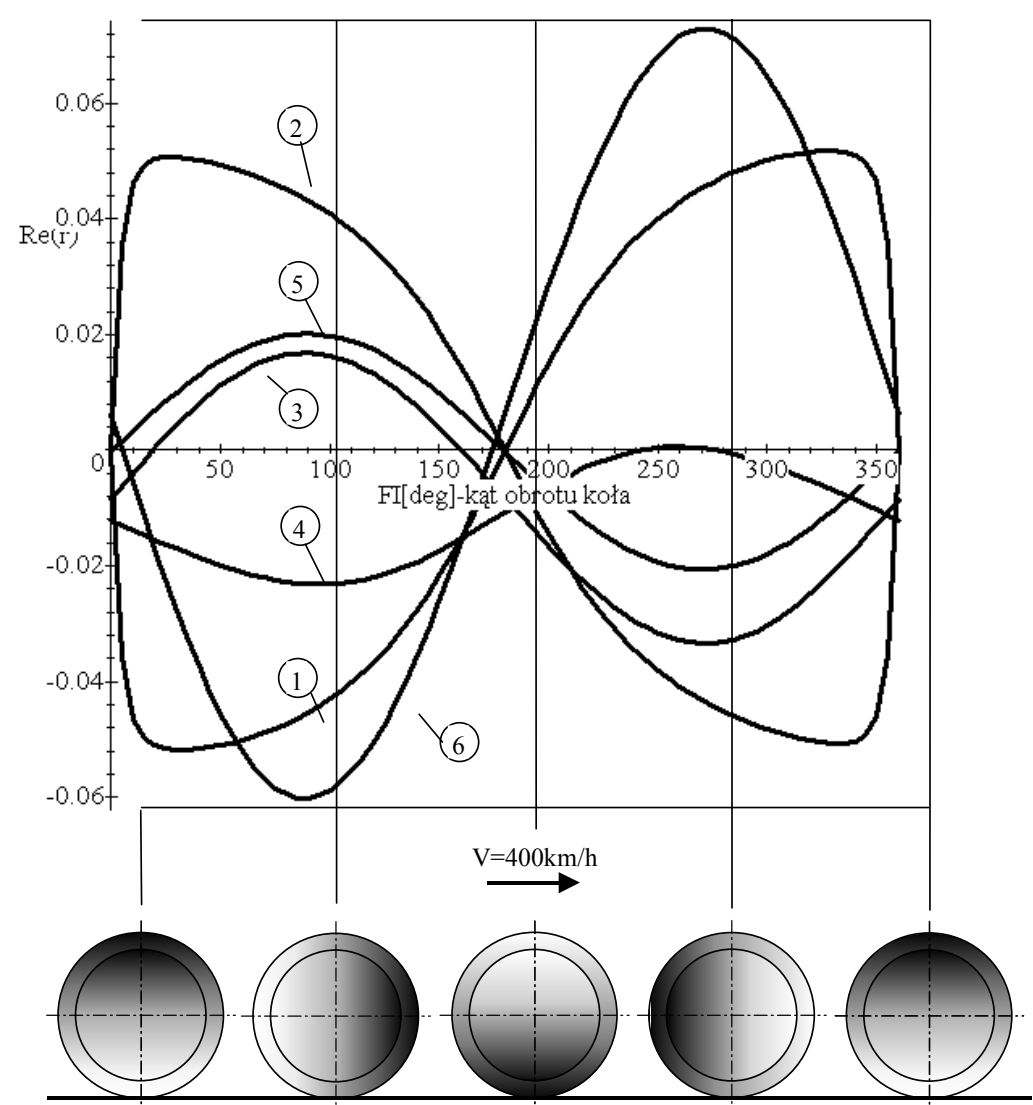

Rys.2. Część rzeczywista $R_{e}$ pierwiastków równania charakterystycznego

\section{Uwagi końcowe}

Przedstawione wyniki obliczeń częstotliwości drgań własnych dla różnych wariantów modelu wirującego koła kolejowego wykazują między sobą istotne różnice jakościowe.

Rozwiązanie zagadnienia brzegowego jednorodnego układu równań opisujących małe drgania koła bez niewyważeń (zachowana symetria kołowa) wykazuje, że każda forma drgań charakteryzuje się skończoną liczbą częstotliwości własnych. Ruch obrotowy koła wywołuje w nim zjawisko bifurkacji częstotliwości, którego źródłem są sprzężenia bezwładnościowe związane $\mathrm{z}$ przyśpieszeniem Coriolisa. Bifurkacja częstotliwości jest przyczyną efektu dudnienia drgań w kole.

$\mathrm{W}$ przypadku koła $\mathrm{z}$ niewyważeniami (asymetria struktury) występuje sprzężenie pomiędzy formami drgań. Drgania formy o numerze $n=0$ (postać z zerową liczbą średnic węzłowych) sprzężone są z drganiami form $k$ i $l(1)$, a formy, dla których $n=1,2,3,4 \ldots \mathrm{z}$ drganiami form $|n-k|,|n-l|, n+k$, i $n+l$. W rezultacie każda postać drgań charakteryzuje się nieskończoną liczbą częstotliwości drgań własnych, wśród których znajdują się częstotliwości dominujące. Identyfikacja tych częstotliwości jest możliwa w wyniku rozwiązania zagadnienia początkowego.

Uwzględnienie współpracy koło/ szyna $\mathrm{w}$ modelu koła $\mathrm{z}$ niewyważeniami poprzez wprowadzenie do modelu matematycznego sił stykowych o postaci (1) oraz uwzględnienie dodatkowego równania (2), pozwala w analizie dynamicznej rozpatrywać rzeczywisty ruch koła kolejowego (ruch toczny). W wyniku rozwiązania zagadnienia brzegowego tak zbudowanego modelu matematycznego stwierdzono $\mathrm{w}$ układzie dynamicznym generowanie dodatkowych wymuszeń o charakterze okresowym. Problem ten jest pod względem jakościowym zagadnieniem nowym i wymaga dalszych szczegółowych badań.

\section{Literatura}

[1] Dżuła S., Falowe równania ruchu wirujacego kota kolejowego z niewyważeniem. Konferencja „Pojazdy Szynowe 2000", Kraków-Arlamów, $t$. II. 